\title{
Canine leishmaniasis in the semi-arid region of Pernambuco, northeastern Brazil: epidemiology, factors associated with seropositivity and spatial analysis
}

\author{
Leishmaniose visceral canina na região semiárida de Pernambuco, \\ nordeste do Brasil: epidemiologia, fatores associados à \\ soropositividade e análise espacial
}

Anna Maria da Cruz Ferreira Evaristo'; Anaiá da Paixão Sevá2; Glauber Meneses Barboza de Oliveira; Ivo Wesley Gomes da Silva'; Matheus Silva Ferreira'; Eline Almeida Rodrigues de Souza'; José Alexandre Menezes Silva4; Sergio Santos Azevedo5; Mauricio Claudio Horta ${ }^{1 *}$ (1)

\footnotetext{
${ }^{1}$ Laboratório de Doenças Parasitárias, Universidade Federal do Vale do São Francisco - UNIVASF, Petrolina, PE, Brasil ${ }^{2}$ Departamento de Modelagem Computacional em Ciência e Tecnologia, Universidade Estadual de Santa Cruz - UESC, Ilhéus, BA, Brasil ${ }^{3}$ Laboratório de Doenças Parasitárias, Departamento de Medicina Veterinária Preventiva, Universidade de São Paulo - USP, São Paulo, SP, Brasil

${ }^{4}$ NHR Brasil, Fortaleza, CE, Brasil

${ }^{5}$ Unidade Acadêmica de Medicina Veterinária, Universidade Federal de Campina Grande - UFCG, Patos, PB, Brasil
}

How to cite: Evaristo AMCF, Sevá AP, Oliveira GMB, Silva IWG, Ferreira MS, Souza EAR, et al. Canine leishmaniasis in the semi-arid region of Pernambuco, northeastern Brazil: epidemiology, factors associated with seropositivity and spatial analysis. Braz J Vet Parasitol 2020; 29(2): e001120. https://doi.org/10.1590/S1984-29612020027

\begin{abstract}
This study aimed to determine the seroprevalence, factors associated with seropositivity to Leishmania infection in dogs and spatial analysis in six municipalities in the semiarid region of Pernambuco, Brazil. Blood samples were collected from 462 dogs, 77 in each municipality, and used for serological analysis [dual path platform (DPP®) and enzyme-linked immunosorbent assay (ELISA)]. Clinical signs of dogs were evaluated and associated factors for Leishmania infection were analyzed using robust Poisson regression model. A seroprevalence of $42.8 \%(198 / 462$, IC: $95 \%=38.6 \%-47.6 \%$ ) was detected in dogs that tested positive in both tests, ranging from $29.8 \%$ to $55.8 \%$, with higher prevalence in the municipality of Cabrobó $(55.8 \%$; P $=0.006)$. About $67 \%(132 / 198)$ of the seropositive dogs showed one or more clinical signs suggestive of canine leishmaniasis (CanL), such as lymphadenomegaly, skin lesions and conjunctivitis, which were associated with seropositivity. High seroprevalence levels were identified in urban and rural areas in all the municipalities, and the buffer for sand flies around cases covered almost these entire areas. Spatial analysis revealed a significant cluster, showing a relative risk of 1.88 in the urban area of Cabrobó. The higher density of seropositive dogs in urban areas indicates the need effective control measures against CanL to prevent the emergence of canine and human diseases.
\end{abstract}

Keywords: Leishmania, diagnosis, serology, dogs, geoprocessing.

\begin{abstract}
Resumo
Este estudo objetivou determinar a soroprevalência, fatores associados com a soropositividade da infecção por Leishmania em cães e análise espacial em seis municípios do semiárido de Pernambuco. Amostras de sangue foram coletadas de 462 cães, 77 em cada município, e utilizadas para análise sorológica [teste rápido imunocromatográfico (DPP ${ }^{\circledast}$ e ensaio de imunoabsorção enzimática (ELISA)]. Os sinais clínicos dos cães foram avaliados, e os fatores associados à infecção por Leishmania foram analisados, usando-se modelo robusto de regressão de Poisson. Foi detectada uma soroprevalência de 42,8\% (198/462, IC: $95 \%=38,6 \%-47,6 \%)$ em cães com resultados positivos em ambos os testes, variando de $29,8 \%$ a 55,8\%, com maior prevalência no município de Cabrobó (55,8\%; P = 0,006). Cerca de $67 \%(132 / 198)$ dos cães apresentaram um ou mais sinais clínicos sugestivos de CanL, como linfadenomegalia, lesões de pele e conjuntivite, os quais foram associados à soropositividade. Altos níveis de soroprevalência foram identificados nas áreas urbanas e rurais de todos os municípios, e os buffers da área de
\end{abstract}

Received January 18, 2020. Accepted April 02, 2020.

*Corresponding author: Mauricio Claudio Horta. E-mail: horta.mc@hotmail.com

This is an Open Access article distributed under the terms of the Creative Commons Attribution License, which permits unrestricted use distribution, and reproduction in any medium, provided the original work is properly cited. 
vôo do flebotomíneo em torno dos casos cobriam quase todas as áreas dos municípios. A análise espacial revelou um cluster significativo, mostrando um risco relativo de 1,88 na área urbana de Cabrobó. A maior densidade de casos em áreas urbanas indica a necessidade de medidas efetivas de controle contra o CanL, para evitar o surgimento da doença canina e humana.

Palavras-chave: Leishmania, diagnóstico, sorologia, cães, geoprocessamento.

\section{Introduction}

Visceral leishmaniasis (VL), a neglected tropical disease of worldwide distribution, is considered a public health problem (WHO, 2017). Every year, 200 to 400 thousand new cases of VL are reported around the world (Alvar et al., 2012; WHO, 2015). VL is present in 18 countries of Americas, and $96 \%(57,582)$ of human cases are reported in Brazil (PAHO, 2019). Dogs are the main domestic reservoir hosts of Leishmania infantum, which is transmitted mainly by the female phlebotomine sand fly Lutzomyia longipalpis, a vector species (Otranto \& Dantas-Torres, 2013; Marcili et al., 2014; Brazil et al., 2015).

The incidence of leishmaniasis is high due to its expansion into urban areas adjacent to residual forests, thereby increasing the number of confirmed cases (Werneck, 2008; Conti et al., 2016). These changes in spatial patterns of transmission provide favorable conditions for the spread of phlebotomine species to peridomiciliary environments, as does the presence of domestic dogs, thus increasing the number of confirmed human cases of leishmaniasis (Conti et al., 2016; Sevá et al., 2017).

Geoprocessing is very useful in epidemiological studies to shed light on the dynamics of VL transmission, because it enables the analysis of spatial correlations between canine (CanL) and human (VL) leishmaniasis, vector distribution, and identification of areas with high incidence levels (Oliveira et al., 2001; Werneck et al., 2007; Teixeira-Neto et al., 2014). The analysis of these issues can contribute toward targeted prevention and control strategies (Marcondes et al., 2011).

Human and canine cases of VL are frequently reported in northeastern Brazil (Dantas-Torres, 2006; Dantas-Torres et al., 2006; Harhay et al., 2011; Belo et al., 2013; Fernandes et al., 2016). From 2007 to 2018, 21,703 human cases were reported in this region, and the state of Pernambuco was particularly affected during this period, with 1,186 human cases reported (SINAN, 2019). Moreover, during this period, there was a wide geographic expansion of the disease in this region (Dantas-Torres, 2006; Pimentel et al., 2015).

The state of Pernambuco is divided into four mesoregions, one of which, located in the semiarid part of the state, is the São Francisco region. High prevalence levels and distribution of CanL have been recorded in this area (Cesse et al., 2001; Dantas-Torres, 2006; Araujo et al., 2016a). The wide distribution of this disease causes the frequent emergence of new cases of human and canine leishmaniasis, particularly in municipalities situated in endemic regions (Araujo et al., 2016b).

Although leishmaniasis is described as an endemic disease in the semiarid region of Pernambuco, and dogs are considered the main reservoirs and crucial for its dissemination, no study has so far focused on the investigation of seroprevalence in dogs in the municipalities of this region, enabling the unperceived perpetuation of the disease. Therefore, this study aimed perform a serological survey, observing spatial distribution and other factors associated with leishmaniasis among dogs in areas endemic for this parasite in the municipalities of this study.

\section{Materials and Methods}

\section{Ethical considerations}

This study was approved by the Research and Ethics Committee of the Federal University of Vale do São Francisco, under Protocol No. 0032/260911.

\section{Study area}

The study was conducted in six municipalities located in the São Francisco region of Pernambuco, in northeastern Brazil (Figure 1). These municipalities, which are served by the Petrolina Regional Public Health Service (VIII GERES)

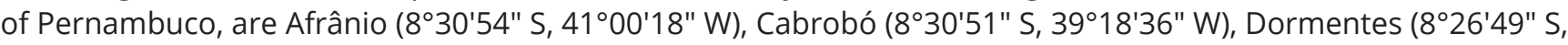
$40^{\circ} 46^{\prime} 15^{\prime \prime}$ W), Lagoa Grande (859'49" S, 40¹6'19" W), Orocó (8³7'12" S, 39³6'7" W) and Santa Maria da Boa Vista 

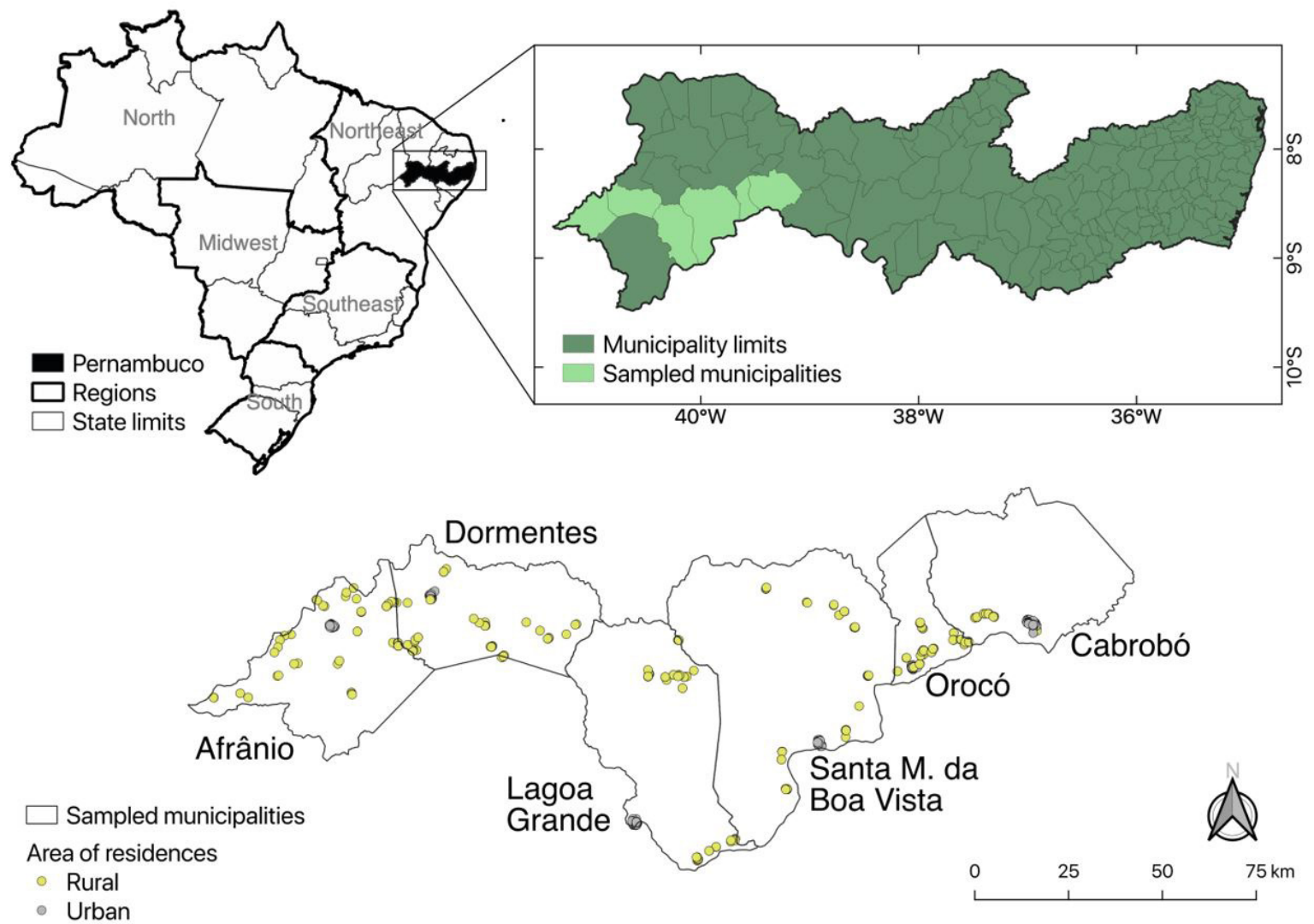

Figure 1. Residences in which the biological samples of dogs were collected in the municipalities (Afrânio, Dormentes, Cabrobó, Lagoa Grande, Orocó and Santa Maria da Boa Vista), in urban and rural areas, located in state of Pernambuco, northeastern Brazil.

$\left(8^{\circ} 48^{\prime} 32^{\prime \prime} \mathrm{S}, 39^{\circ} 49^{\prime} 30^{\prime \prime} \mathrm{W}\right)$. The area is situated in the semi-arid region, characterized mainly by Caatinga biome with stretches of hyperxerophile deciduous forest (IBGE, 2011). An annual average of nine human cases of VL were reported in these municipalities between 2007 and 2017 (SINAN, 2018).

\section{Sampling procedures and clinical examination}

The study was conducted from June 2016 to December 2017. The sample size was determined using Epi Info version 7.1 software, with a 95\% confidence interval, $2 \%$ margin of error, and an estimated prevalence of $11.2 \%$ (Araujo et al., 2016b). Considering the calculation for an infinite population, the sample size required for our study was approximately 462 dogs, comprising 77 animals per municipality (Table 1), divided between urban and rural areas (UA and RA) (Figure 1).

Table 1. Number of samples to be collected according to the human population in each urban and rural area of the municipalites.

\begin{tabular}{|c|c|c|c|c|c|c|c|}
\hline Municipalities & Urban Pop. & $\%$ & Samples & Rural Pop. & $\%$ & Samples & Total Pop. \\
\hline Afrânio & 5,859 & 33.3 & 26 & 11,729 & 66.7 & 51 & 17,588 \\
\hline Cabrobó & 19,811 & 64.1 & 49 & 11,072 & 35.9 & 28 & 30,883 \\
\hline Dormentes & 6,004 & 35.5 & 27 & 10,911 & 64.5 & 50 & 16,915 \\
\hline L. Grande & 10,369 & 45.6 & 35 & 12,350 & 54.4 & 42 & 22,719 \\
\hline Orocó & 4,614 & 35.0 & 27 & 8,562 & 65.0 & 50 & 13,176 \\
\hline S.M.B.V & 14,861 & 37.6 & 29 & 24,612 & 62.4 & 48 & 39,473 \\
\hline Total & 61,518 & & 193 & 79,236 & & 269 & 140,754 \\
\hline
\end{tabular}

S.M.B.V = Santa Maria da Boa Vista, L = Lagoa, Pop = Population. 
The number of blood samples to be collected in each municipality was determined based on the human population living in each neighborhood of the municipality, according to data provided by the Brazilian Institute of Geography and Statistics (IBGE). Sampling points were selected randomly, and blood samples were collected only from dogs 6 months or older that had not been vaccinated against leishmaniasis.

Approximately $4 \mathrm{~mL}$ of blood were collected by cephalic venipuncture from each animal. The blood serum was obtained by centrifugation and was stored at $-20^{\circ} \mathrm{C}$ for subsequent serological analysis.

Information was obtained about the sex, age, breed, dog pelage and size of each animal. Each dog was physically examined by a veterinarian to identify the main clinical signs of CanL, as emaciation, epistaxis, icterus, pale mucous membranes (ocular and oral), lymphadenomegaly (evaluation of the main popliteal, prescapular and submandibular lymph nodes), hepatosplenomegaly (by abdominal palpation), cutaneous alterations (alopecia, dermatitis, ulcers, lesions on the ears, face and limbs), cachexia, onychogryphosis and conjunctivitis (Amusategui et al., 2003; Alvar et al., 2004).

\section{Serological diagnosis}

Serum samples were tested by two different methods to detect the presence of anti-Leishmania IgG antibodies. The first was qualitative screening by the Dual Path Platform (DPP ${ }^{\circledR}$ ) rapid immunochromatographic test, produced by Fiocruz (Bio-Manguinhos Unit, Rio de Janeiro, Brazil), which contains a multi-epitope, recombinant chimeric protein ( $\mathrm{rK} 28$ ) derived from the fusion of $L$. infantum gene k9, single repeat units of k39 and k26 (Boarino et al., 2005). All the procedures were performed as recommended by the manufacturer. The second method was the confirmatory quantitative test using a commercial ELISA kit (IMUNOTESTE ${ }^{\circledR}$ Leishmania; Imunodot, Jaboticabal, São Paulo, Brazil), also performed as recommended by the manufacturer. The cut-off value was determined as the mean absorbance value of the negative controls (provided with the kit) multiplied by 2.5, with all the readings above the cut-off value considered positive. Absorbance was read at $405 \mathrm{~nm}$ on an automated EL $800 \mathrm{G}$ ELISA microplate reader (Bio-Tek Instruments, Winooski, VT, USA).

\section{Factors associated with seropositivity}

The head of each household was asked to answer a comprehensive questionnaire to provide information about independent variables that could be associated with seroreactivity to L. infantum (dependent variables), to describe the general and individual characteristics of the canine population and their environment, and to determine the factors associated with seropositivity for CanL.

The following variables were considered: breed (mongrel or purebred), sex (male or female), age (up to 12, 13 to 84, or $>84$ months), dog pelage (light or dark), size (small, medium or large), presence of green area/trees (yes/no), urban area (yes/no), rural area (yes/no), street access (yes/no), contact with other animals (yes/no), veterinary care (yes/no), contact with forest/Caatinga (yes/no), interaction with wildlife (yes/no), presence of a chicken coop (yes/no), and human cases of leishmaniasis (in the household and/or neighborhood).

To conduct the analysis of factors associated with seroprevalence, univariable analysis was initially performed, in which each independent variable underwent an association analysis in relation to the dependent variable (positivity in serological tests). Variables with $P$-value $\leq 0.2$ in the Chi-square test or Fisher's exact test were selected for multivariable analysis using robust Poisson regression. Collinearity between independent variables was verified by a correlation analysis; for those variables with a strong collinearity (correlation coefficient $>0.9$ ), one of the two variables was excluded from the multiple analysis according to the biological plausibility (Dohoo et al., 2003). To assess how well the model fits the Person Chi-square was used, and the significance of the model was verified with Omnibus test. The significance level adopted in the multiple analysis was 5\%, and the software used was SPSS for Windows version 20.0.

\section{Spatial analysis}

The geographical coordinates of sampled households were determined by GPS (global positioning satellite). The data were combined using $\mathrm{QGIS}^{\circledR} \mathrm{v}$. 2.18 software to create spatial maps.

Kernel density mapping was employed to visually identify hotspots in the municipalities, indicating the occurrence of an event concentration and the agglomeration of positive cases in a spatial distribution (Pfeiffer et al., 2008). 
A spatial cluster analysis was done to detect areas with significant incidence levels, using the local cluster evaluation method developed by Kulldorff \& Nagarwalla (1995) and SaTScan 9.5 version software.

Given that the average flight radius of the vector of VL is $250 \mathrm{~m}$ (Oliveira et al., 2013), buffer zones of $250 \mathrm{~m}$ were simulated around seropositive dogs to identify areas of greater risk for the presence of infected vectors, and therefore for the disease in dogs and humans.

\section{Results}

The serological tests to detect the presence of antibodies to L. infantum revealed positivity levels of $58.8 \%$ (272/462) by DPP ${ }^{\circledR}(25.1 \%$ in the urban area - UA and 33.7\% in the rural area - RA) and $43.9 \%$ (203/462) by ELISA (21.2\% in the UA and $22.7 \%$ in the RA). Prevalence data were calculated based on the number of dogs seropositive by both DPP ${ }^{\circledR}$ and ELISA, showing an overall seroprevalence of 42.8\% (198/462, IC: 95\% $\left.=38.6 \%-47.6 \%\right)$. Seroprevalence was significantly higher $(P=0.003)$ in UA than in RA, i.e., $51 \%(98 / 192$ IC: $95 \%=44.19 \%-58.3 \%)$ as opposed to $37 \%$ (100/270 IC: $95 \%=31.8 \%-43.4 \%)$. Seropositivity levels among dogs in the municipalities were as follows: Cabrobó 55.8\% (43/77), Lagoa Grande 46.7\% (36/77), Orocó 45.4\% (35/77), Santa Maria da Boa Vista 46.7\% (36/77), Dormentes 32.4\% (25/77), and Afrânio 29.8\% (23/77) (Table 2).

Table 2. Prevalence of anti-Leishmania spp. antibod.ies in dogs in urban and rural areas from six municipalities, State of Pernambuco, Brazil. Prevalence \% (seropositive dogs/tested dogs).

\begin{tabular}{|c|c|c|c|c|c|c|c|c|c|}
\hline \multirow[b]{2}{*}{ Municipalities } & \multicolumn{9}{|c|}{ Serological tests } \\
\hline & $\begin{array}{c}\text { DPP }^{\circledR} \\
\text { UA }\end{array}$ & $\begin{array}{c}\text { DPP }^{\circledast} \\
\text { RA }\end{array}$ & $\begin{array}{l}\text { DPP } \\
\text { Total }\end{array}$ & $\begin{array}{c}\text { ELISA } \\
\text { UA }\end{array}$ & $\begin{array}{c}\text { ELISA } \\
\text { RA }\end{array}$ & $\begin{array}{l}\text { ELISA } \\
\text { Total }\end{array}$ & $\begin{array}{c}\text { DPP } \\
+ \text { ELISA } \\
\text { UA }\end{array}$ & $\begin{array}{c}\text { DPP }{ }^{\circledR} \\
+ \text { ELISA } \\
\text { RA }\end{array}$ & $\begin{array}{c}\text { DPP } \\
+ \text { ELISA } \\
\text { Total }\end{array}$ \\
\hline Afrânio & $23.1(6 / 26)$ & $51(26 / 51)$ & $41.5(32 / 77)$ & $19.2(5 / 26)$ & $43.1(22 / 51)$ & $35.1(27 / 77)$ & $19.2(5 / 26)$ & $35.3(18 / 51)$ & $29.8(23 / 77)$ \\
\hline Cabrobó & $89.8(44 / 49)$ & $53.6(15 / 28)$ & $76.6(59 / 77)$ & $71.4(35 / 49)$ & $28.6(8 / 28)$ & $56(43 / 77)$ & $71.4(35 / 49)$ & $28.6(8 / 28)$ & $55.8(43 / 77)$ \\
\hline Dormentes & $37(10 / 27)$ & $62(31 / 50)$ & $53.2(41 / 77)$ & $37(10 / 27)$ & $32(16 / 50)$ & $33.8(26 / 77)$ & $37(10 / 27)$ & $30(15 / 50)$ & $32.4(25 / 77)$ \\
\hline L. Grande & $48.7(17 / 35)$ & $69(29 / 42)$ & $59.7(46 / 77)$ & $48.7(17 / 35)$ & $45.2(19 / 42)$ & $46.8(36 / 77)$ & $48.6(17 / 35)$ & $45.2(19 / 42)$ & $46.7(36 / 77)$ \\
\hline Orocó & $70.4(19 / 27)$ & $58(29 / 50)$ & $62.3(48 / 77)$ & $66.6(18 / 27)$ & $34(17 / 50)$ & $45.5(35 / 77)$ & $67(18 / 27)$ & $34(17 / 50)$ & $45.4(35 / 77)$ \\
\hline S. M. B. V & $69(20 / 29)$ & $54.2(26 / 48)$ & $59.7(46 / 77)$ & $44.8(13 / 29)$ & $48(23 / 48)$ & $46.8(36 / 77)$ & $45(13 / 29)$ & $48(23 / 48)$ & $46.7(36 / 77)$ \\
\hline
\end{tabular}

$\mathrm{DPP}^{\circledast}=$ Dual Path Platform,UA = Urban Area, RA = Rural Area, L. = Lagoa, S.M.B.V = Santa Maria da Boa Vista.

With regard to possible associations between independent variables and seropositivity among dogs (Table 3), the variables municipalities, age (months), breed, presence of green areas/trees, area, and dog pelage were selected for multivariate analysis $(P \leq 0.20)$.

Clinical signs compatible with CanL were detected in 64.9\% (300/462) of the sampled dogs. Approximately $67 \%(132 / 198)$ of the seropositive animals presented clinical signs. Table 4 describes the most frequent clinical signs shown by seropositive dogs. These signs, which included lymphadenomegaly in prescapular lymph nodes $(P=0.097)$, popliteal lymph nodes $(P=0.181)$, submandibular lymph nodes $(P=0.130)$, ocular lesions $(P=0.192)$, conjunctivitis $(P=0.102)$, lesions around the ears $(P=0.143)$, face $(P=0.102)$ and limbs $(P=0.102)$, selected for multivariate analysis $(P \leq 0.20)$.

The multiple analysis of independent variables described in Table 5 enabled the identification of factors associated with seropositivity for CanL. These factors were significantly associated with the prevalence of $L$. infantum antibodies $(P \leq 0.05)$ among 13 to 84-month-old dogs $(P=0.010)$, light pelage $(P=0.007)$, living in the municipality of Cabrobó $(P=0.006)$ and Lagoa Grande $(P=0.017)$ or in rural area $(P=0.039)$. The model presented good fit (Pearson Chi-square: value $=266.10$; degrees of freedom $-\mathrm{df}=499$; value $/ \mathrm{df}=0.593$ ) and statistical significance (Omnibus test: likelihood ratio Chi-square $=22.40 ; \mathrm{df}=12 ; P=0.033$ ).

The location of households with positive and negative dogs indicated that they were widely distributed in the six municipalities of this study (Figure 2).

The kernel map shows the spatial density of seropositive cases, revealing a higher concentration of seropositive dogs in the urban areas of the municipalities (Figure 3). 
Overall, the local spatial analysis showed only one significant cluster of high incidence of seropositivity with a p-value of $0.01(P \leq 0.05)$ (Table 6) located in the municipality of Cabrobó (Figure 4).

Based on the buffer zones, significant agglomerations of positive dogs were identified in each municipality, mostly in urban areas (Figure 5).

Table 3. Univariate analysis with the distribution of the variables associated with Leishmania spp. in dogs from Afrânio, Cabrobó, Dormentes, Lagoa Grande, Orocó and Santa Maria da Boa Vista municipalities, State of Pernambuco, Brazil.

\begin{tabular}{|c|c|c|c|c|}
\hline Variable & Category & Total number of dogs & Positives (\%) & P-value \\
\hline \multirow[t]{6}{*}{ Municipalities } & Afrânio & 77 & $23(29.8)$ & $0.010^{*}$ \\
\hline & Cabrobó & 77 & $43(55.8)$ & \\
\hline & Dormentes & 77 & $25(34.4)$ & \\
\hline & L. Grande & 77 & $36(46.7)$ & \\
\hline & Orocó & 77 & $35(45.4)$ & \\
\hline & S. M. B. V & 77 & $36(46.7)$ & \\
\hline \multirow[t]{3}{*}{ Age (months) } & up to 12 & 123 & $41(33.3)$ & $0.032^{*}$ \\
\hline & 13 to 84 & 297 & $140(47.1)$ & \\
\hline & $>84$ & 42 & $17(40.4)$ & \\
\hline \multirow[t]{2}{*}{ Breed } & mongreal & 425 & $177(41.6)$ & $0.108^{*}$ \\
\hline & purebreed & 37 & $21(56.7)$ & \\
\hline \multirow[t]{2}{*}{ Presence of green area/trees } & no & 105 & $51(48.5)$ & $0.178^{*}$ \\
\hline & yes & 357 & $147(41.1)$ & \\
\hline \multirow[t]{2}{*}{ Area } & rural & 270 & $100(37)$ & $0.004^{*}$ \\
\hline & urban & 192 & $98(51)$ & \\
\hline \multirow[t]{2}{*}{ Dog pelage } & light & 284 & $135(47.5)$ & \\
\hline & dark & 178 & $63(35.4)$ & $0.014 *$ \\
\hline
\end{tabular}

*Variables selected for multivariate analysis ( $\mathrm{P} \leq 0.2)$. L = Lagoa, S.M.B.V = Santa Maria da Boa Vista.

Table 4. The recorded clinical signs in the total sample and in the dogs that were seropositivity for anti-Leishmania infantum antibodies.

\begin{tabular}{|c|c|c|c|c|}
\hline Clinical signs & $\begin{array}{c}\text { Total number of } \\
\text { dogs presenting the } \\
\text { sign }\end{array}$ & $\begin{array}{c}\text { Total number of } \\
\text { seropositive dogs } \\
\text { presenting the sign }\end{array}$ & Seroprevalence (\%) & P-value \\
\hline \multicolumn{5}{|c|}{ Lymph node Prescapular } \\
\hline No & 311 & 125 & 40.1 & $0.097^{*}$ \\
\hline Yes & 151 & 73 & 48.3 & \\
\hline \multicolumn{5}{|c|}{ Lymp node Popliteal } \\
\hline No & 273 & 110 & 40.2 & $0.181 *$ \\
\hline Yes & 189 & 88 & 46.5 & \\
\hline \multicolumn{5}{|c|}{ Lymp node submandibular } \\
\hline No & 385 & 159 & 41.2 & $0.130 *$ \\
\hline Yes & 77 & 39 & 50.6 & \\
\hline \multicolumn{5}{|l|}{ Ocular Lesions } \\
\hline No & 458 & 195 & 42.5 & $0.192 *$ \\
\hline Yes & 4 & 3 & 75 & \\
\hline \multicolumn{5}{|l|}{ Conjunctivitis } \\
\hline No & 460 & 196 & 42.6 & $0.102 *$ \\
\hline Yes & 2 & 2 & 100 & \\
\hline \multicolumn{5}{|c|}{ Lesion on the ears } \\
\hline No & 421 & 176 & 41.8 & $0.143^{*}$ \\
\hline Yes & 41 & 22 & 53.6 & \\
\hline \multicolumn{5}{|l|}{ Face Lesion } \\
\hline No & 460 & 196 & 42.6 & $0.102^{*}$ \\
\hline Yes & 2 & 2 & 100 & \\
\hline \multicolumn{5}{|l|}{ Limb Lesion } \\
\hline No & 457 & 194 & 42.4 & $0.102^{*}$ \\
\hline Yes & 5 & 4 & 80 & \\
\hline
\end{tabular}

* Variables selected for multivariate analysis $(P \leq 0.2)$. 
Table 5. Multivariate analysis (robust Poisson regression) with the factors associated with Leishmania spp. seropositivity in dogs from Afrânio, Cabrobó, Dormentes, Lagoa Grande, Orocó and Santa Maria da Boa Vista municipalities, State of Pernambuco, Brazil.

\begin{tabular}{ccccccc}
\hline Variable category & $\begin{array}{c}\text { Coefficient } \\
\text { estimates }\end{array}$ & $\begin{array}{c}\text { Standard } \\
\text { error }\end{array}$ & $\begin{array}{c}\text { Wald } \\
\text { Chi-square }\end{array}$ & $\begin{array}{c}\text { Prevalence } \\
\text { ratio }\end{array}$ & $\begin{array}{c}95 \% \\
\text { confidence } \\
\text { interval }\end{array}$ & $\begin{array}{c}\text { P-value } \\
\text { Rural area }\end{array}$ \\
Light pelage & 0.236 & 0.115 & 4.239 & 1.27 & $1.01 ; 1.59$ & 0.039 \\
Age of 13 to 84 months & 0.332 & 0.123 & 7.282 & 1.39 & $1.10 ; 1.78$ & 0.007 \\
Municipality of Cabrobó & 0.366 & 0.143 & 6.581 & 1.44 & $1.09 ; 1.91$ & 0.010 \\
Municipality of Lagoa Grande & 0.555 & 0.201 & 7.616 & 1.74 & $1.18 ; 2.58$ & 0.006 \\
\hline
\end{tabular}
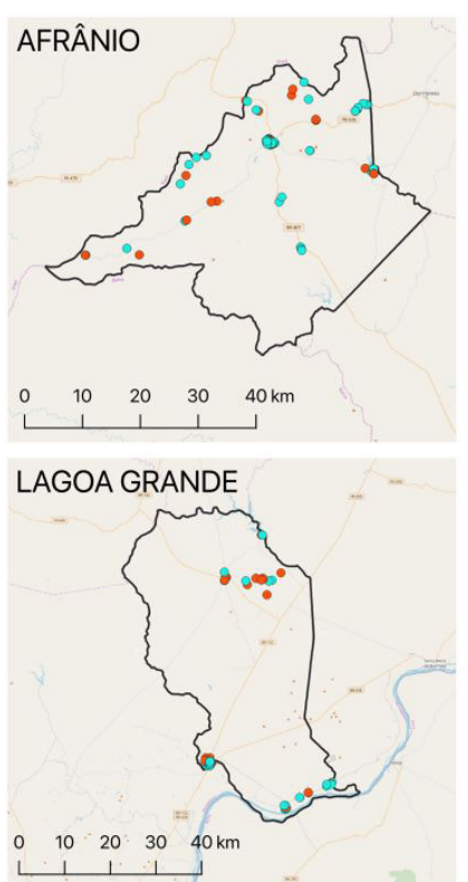

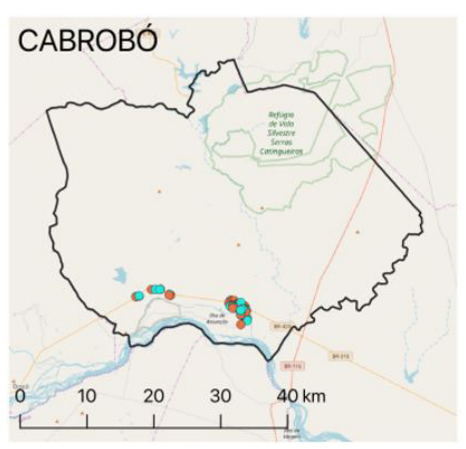

DORMENTES

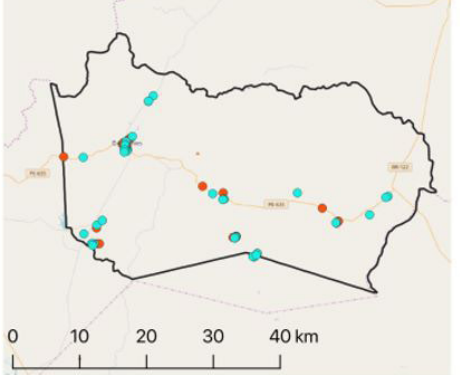

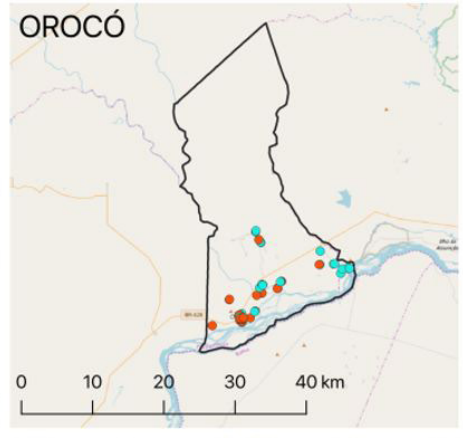

STA M. DA BOA VISTA

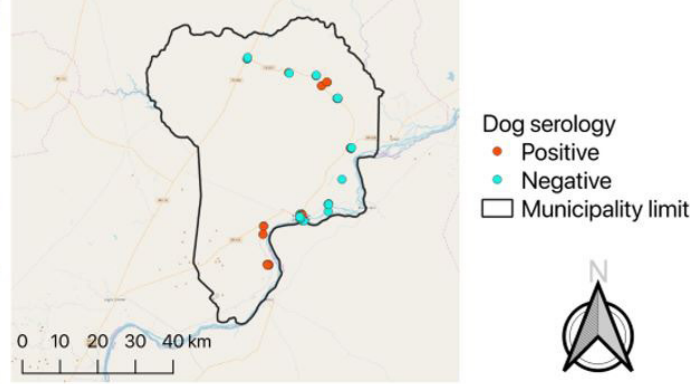

Figure 2. Distribution of dogs that were seropositive for the presence of anti-Leishmania spp. antibodies in the municipalities of Afrânio, Cabrobó, Dormentes, Lagoa Grande, Orocó and Santa Maria da Boa Vista, state of Pernambuco, northeastern Brazil.

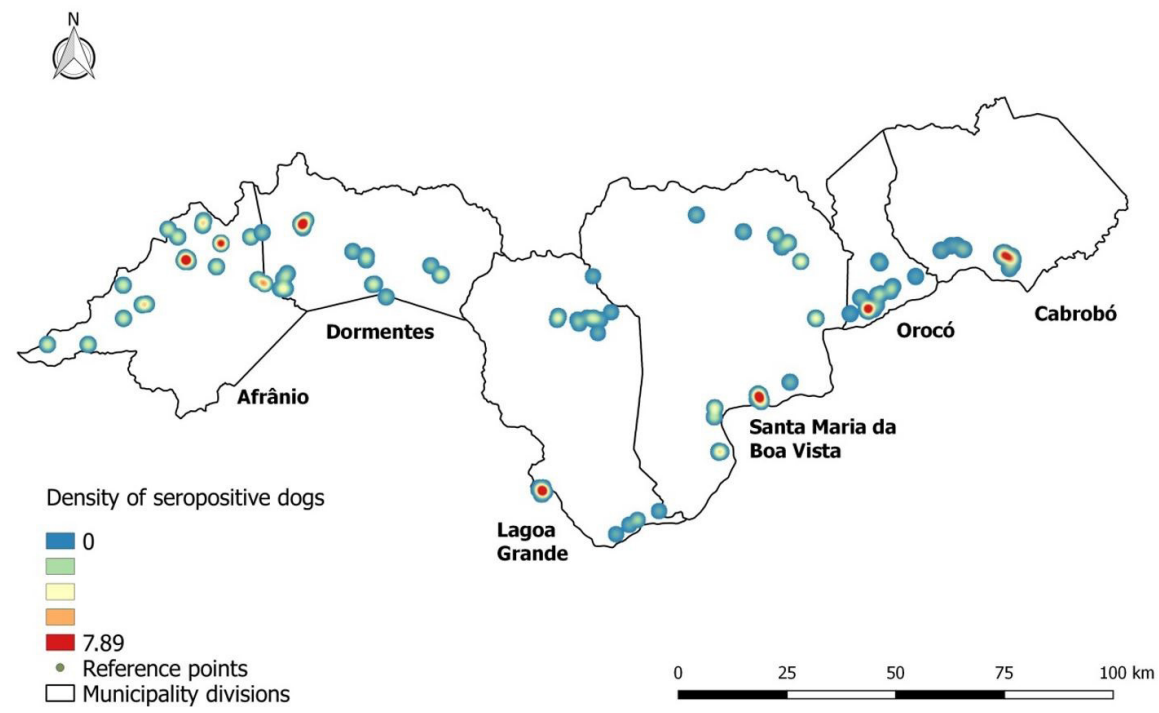

Figure 3. Kernel density mapping for canine leishmania infection in the municipalities of Afrânio, Dormentes, Lagoa Grande, Orocó and Santa Maria da Boa Vista, state of Pernambuco, northeastern Brazil. 
Table 6. Local cluster analysis results using spatial scan statistics.

\begin{tabular}{|c|c|c|c|c|c|c|c|c|}
\hline & \multicolumn{2}{|c|}{ Cabrobó } & \multicolumn{2}{|c|}{ Orocó } & \multicolumn{2}{|c|}{ L. Grande } & \multicolumn{2}{|c|}{ S.M.B.V } \\
\hline & DC & OCA & DC & OCA & DC & OCA & DC & OCA \\
\hline Population & 43 & 34 & 27 & 50 & 5 & 72 & 4 & 73 \\
\hline Positives & 32 & 11 & 21 & 14 & 5 & 31 & 4 & 32 \\
\hline Prevalence (\%) & 74.4 & 32.3 & 77.8 & 28 & 46.7 & 43 & 46.7 & 43.8 \\
\hline $\mathrm{RR}^{*}$ & 1.88 & & 1.91 & & 2.37 & & 2.36 & \\
\hline p-value & $0.010 *$ & & 0.105 & & 0.934 & & 0.999 & \\
\hline Radius (Km) & 1.62 & & 2.27 & & 0.35 & & 0.29 & \\
\hline
\end{tabular}

$\star(P \leq 0.05)$;CRR: Reltive Risck, DC= Detected Cluster, OCA= Out of Cluster Area, L. = Lagoa, S.M.B.V= Santa Maria da Boa Vista.

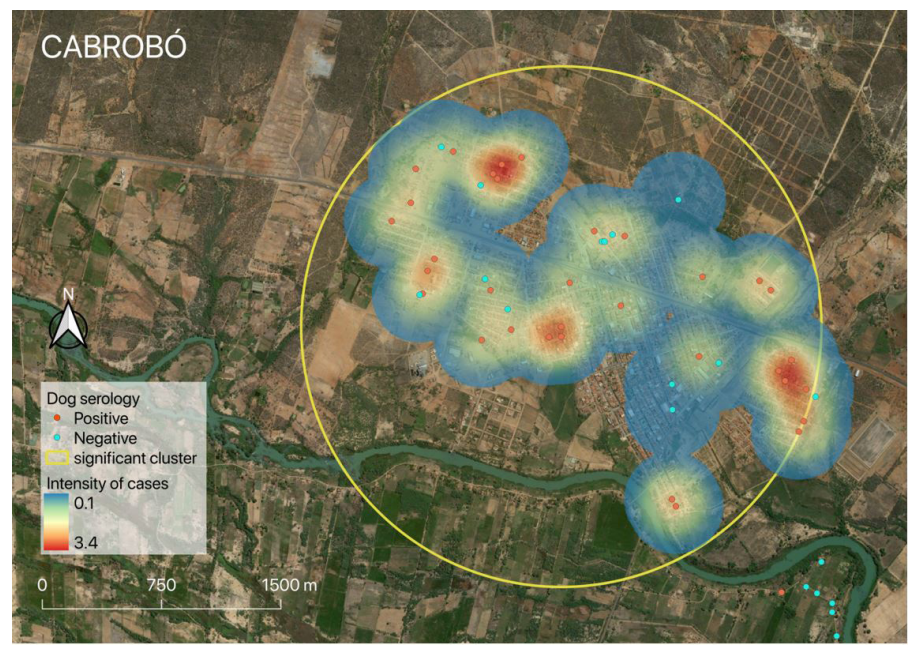

Figure 4. Location of the cluster and intensity cases of positive animals in the municipality of Cabrobó, state of Pernambuco, northeastern Brazil.
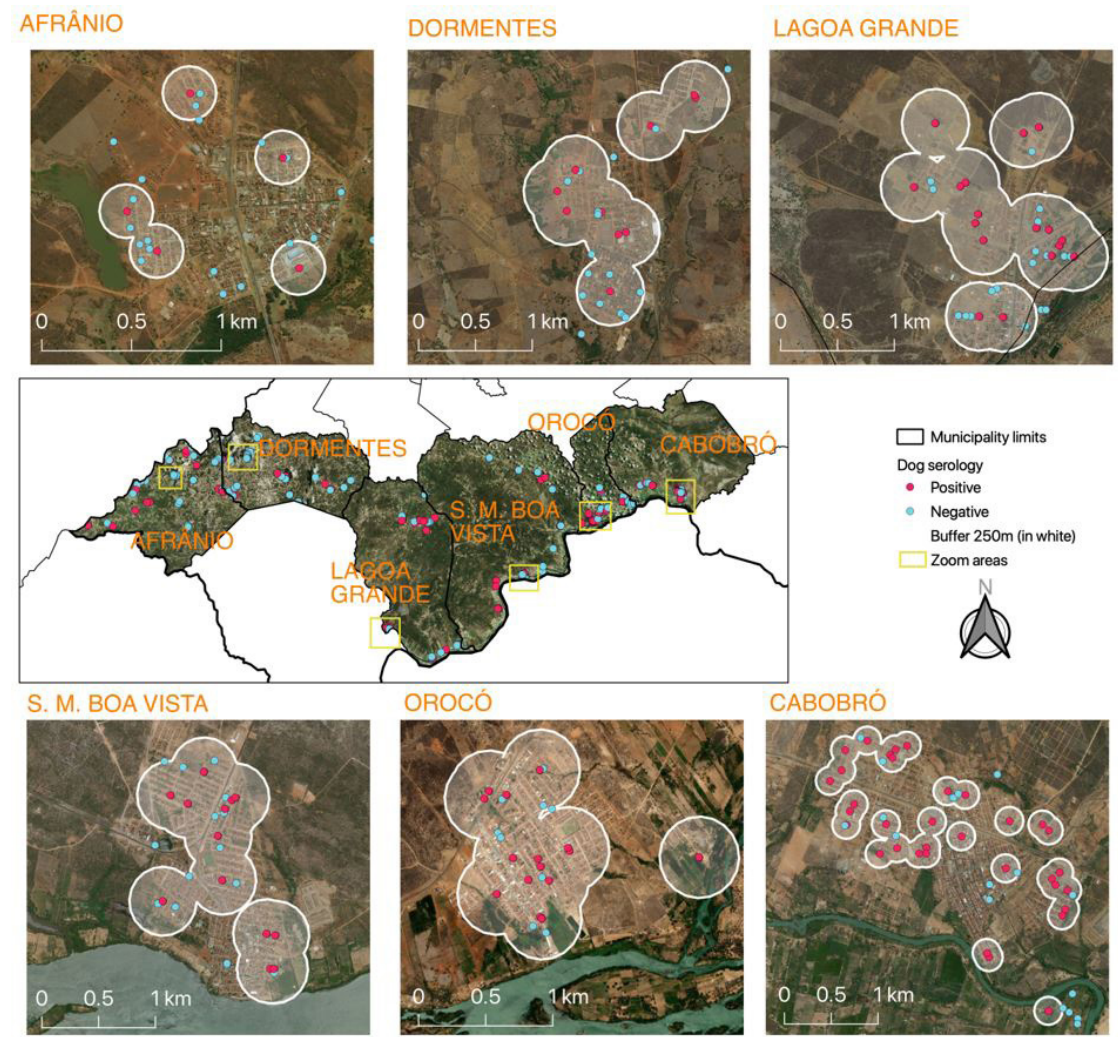

Figure 5. Buffer with a $250 \mathrm{~m}$ radius generated around seropositives dogs for Leishmania spp. in the municipalities of Afrânio, Cabrobó, Dormentes, Lagoa Grande, Orocó and Santa Maria da Boa Vista, state of Pernambuco, northeastern Brazil. Clusters of cases were observed in urban area of main districts of each municipality. 


\section{Discussion}

The study area, which presented high VL incidence and prevalence levels, is considered an endemic area of intense transmission due to a combination of environmental and socioeconomic factors (Cesse et al., 2001; Maia et al., 2014).

Reported CanL prevalence levels vary depending on which serological test is used, on the canine population, and on the region under study (Julião et al., 2007; Silva et al., 2016; Belo et al., 2017; Silva et al., 2017). This has been demonstrated in various studies carried out in Brazil's northeast, south and central west regions (Santis et al., 2013; Leça et al., 2015; Belo et al., 2017).

Domestic dogs are the main urban reservoirs of L. infantum in zoonotic VL transmission (Belo et al., 2013). Therefore, knowledge about the epidemiological profile of CanL in important endemic regions such as northeastern Brazil and about risk factors associated with the infection in dogs is crucial, contributing toward control of the disease and the development of strategies for serological surveys in the region, focusing specifically on this silent disease (Dantas-Torres, 2006; Dantas-Torres et al., 2006; Marcondes et al., 2011; Laurenti et al., 2013).

This study is the first CanL serosurvey conducted in various municipalities of the São Francisco mesoregion (Afrânio, Cabrobó, Dormentes, Lagoa Grande, Orocó and Santa Maria da Boa Vista) located in the semi-arid region of northeastern Brazil. The mean prevalence of anti-L. infantum IgG antibodies was $42.8 \%$, ranging from $29.8 \%$ to $55.8 \%$. These values are higher than those reported in other endemic areas in northeast Brazil (Lira et al., 2006; Queiroz et al., 2010; Pimentel et al., 2015; Mendonça et al., 2017; Silva et al., 2017) and in Petrolina, in the state of Pernambuco, where a prevalence of $11.2 \%$ was reported (Araujo et al., 2016b). In Petrolina, situated in the same mesoregion as this study, the reported number of seropositive dogs was low compared to that of our study, possibly because the indirect fluorescent antibody test (IFAT) was used, which is more specific (Laurenti et al., 2014), and more sensitive (Adams et al., 2012; Silva et al., 2013b) than the DPP method.

Although ELISA is widely used in this country, Brazil's Ministry of Health recommends the use of a protocol that combines two sensitive tests (DPP ${ }^{\circledR}$ and ELISA) (Travi et al., 2018). This may negatively influence canine serological diagnosis, resulting in numerous false positives and thus overestimating prevalence levels (Laurenti et al., 2014; Arruda et al., 2016). However, the Ministry of Health continues to favor the use of these tests, which are extensively used because they are fast and easy to perform, enabling the analysis of numerous samples in a short time (Grimaldi et al., 2012; Silva et al., 2016). The detection of clinical signs in infected dogs is important for the early diagnosis of suspected cases of the CanL, and the presence of these signs pertains mainly to the immune-mediated nature of this disease, causing the parasite to multiply in the host's tissues (Dantas-Torres, 2007; Queiroz et al., 2010; Michelin et al., 2018). The researchers Almeida et al. (2005), Baneth et al. (2008) and Silva et al. (2017) reported that, in their studies, most of the dogs seropositivity for CanL were clinically affected. This finding is similar to that of our study, in which $66.6 \%(132 / 198)$ of the dogs wereclinically affected, with lymphadenomegaly and skin lesions being the most prevalent clinical signs. Conjunctivitis and ocular lesions, which were clinical signs commonly exhibited by infected dogs in our study, were also reported by Cordeiro et al. (2016).

The univariate analysis revealed an association between mongreal dogs and seropositivity for CanL. Among the factors that make these animals more vulnerable to infection are unhindered access to the street and to contact with the sand fly vector, as well as immunosuppression due to a high degree of malnutrition (Cortes et al., 2012; Silva et al., 2013a, 2016).

The multivariate analysis indicated that 13 to 84 -month-old dogs were more predisposed to become infected with CanL. This finding corroborates studies by Paltrinieri et al. (2010) and Rondon et al. (2008), who associated the higher susceptibility of this age group to their immature immune system, making them more susceptible to infection. In addition, Alvar et al. (2004) state that 8-year-old animals may be serologically positive due to prolonged immune response.

The analysis of risk factors in this study showed a direct association between seropositivity levels and living in rural areas, coinciding with the findings of Silva-Abreu et al. (2008), Silva et al. (2013a) and Leça et al. (2015). Although the change in the spatial transmission pattern of the disease began in the 1990s (Harhay et al., 2011), in rural area the presence adjacent to residual forests, accumulation of organic matter and the diversity animals, favors the presence of phlebotomine sand flies and reservoirs of Leishmania spp. in the environment (Camargo-Neves et al., 2001).

Living in Cabrobó and Lagoa Grande was also a risk factor showed. This suggests the need for the adoption of more effective leishmaniasis control and prevention measures to reduce the impact of environmental and 
peridomiciliary factors, such as intense population pressure on the environment and the ruralization of some urban areas, lack of garbage collection, poor sanitation, presence of the vector, and the canine population (Dantas-Torres, 2007; Santos et al., 2010; Michel et al., 2011; Belo et al., 2013).

Spatial analysis tools used in research into the prevalence and incidence of VL are essential to garner epidemiological data from a specific area, in order to identify sites where cases of the disease are concentrated and thereby contribute toward the design of effective measures of control and prevention (Borges et al., 2014; Teixeira-Neto et al., 2014; Oliveira et al., 2015).

The high concentration of cases in the urban areas of the six municipalities of this study, revealed by kernel density maps, can be attributed to the higher concentration of reservoir hosts, such as dogs. Kernel mapping enables the implementation of epidemiological surveillance, thus contributing to control and prevent the disease in these areas (Dujardin, 2006; Araujo et al., 2016b).

An analysis of the clusters of CanL cases revealed a significant cluster in the municipality of Cabrobó, where dogs are at 1.88-fold higher risk of infection than in other locations. This finding indicates that the probability of the emergence of new cases of seropositive dogs is greater in this area (Carvalho \& Souza-Santos, 2005; Dantas-Torres, 2006). Given the positive correlation between canine and human cases of $\mathrm{VL}$, it is reasonable to postulate that this high risk of canine infection in Cabrobó may also represent a risk for transmission of the disease to humans (Oliveira et al., 2001; Souza et al., 2012).

The $250 \mathrm{~m}$ buffer zones created around CanL cases enable one to identify significant clusters of positive dogs and to pinpoint areas where the infecting vector may be present more frequently. The UAs were almost entirely covered by buffer zones in all the municipalities except Afrânio. This analysis shows where public health actions are needed most urgently to prevent the emergence of new cases. It also indicates the need for entomological research to prevent the perpetuation of the vector population, given the favorable conditions of these areas for its maintenance (Abrantes et al., 2018).

In conclusion, our findings suggest a high prevalence of Leishmania spp. in the six municipalities of the semi-arid mesoregion of Pernambuco. The most common clinical signs found in seropositive dogs were lymphadenomegaly, skin lesions and conjunctivitis, and the risk factors most strongly correlated with the presence of positive dogs were the 13 to 84-month-old age group and living in rural areas and/or in the municipality of Cabrobó.

\section{Acknowledgements}

We would like to thank to Deborah Rodrigues, Mateus Granja, Lauricia Nascimento, and Naylla Mayanna for her collaboration during blood collection; the Fundação de Amparo à Ciência e Tecnologia do Estado de Pernambuco (FACEPE) for the financial support and scholarship (IBPG 1335-5.05/2016 to A.M.C.F Evaristo); to the Secretaria Municipal de Saúde (SMS) of Petrolina, PE and the VIII Gerência Regional de Saúde (GERES) by collaboration in the implementation of DPP ${ }^{\circledR}$ and ELISA. MCH is the recipient of a research fellowship from CNPq (bolsa de produtividade; grant number: 308668/2018-9).

\section{References}

Abrantes TR, Werneck GL, Almeida AS, Figueiredo FB. Environmental factors associated with canine Visceral Leishmaniasis in an area with recent introduction of the disease in the State of Rio de Janeiro, Brazil. Cad Saude Publica 2018; 34(1): 7-10. http:// dx.doi.org/10.1590/0102-311x00021117. PMid:29412315.

Adams ER, Jacquet D, Schoone G, Gidwani K, Boelaert M, Cunningham J. Leishmaniasis Direct agglutination test: using pictorials as training materials to reduce inter-reader variability and improve accuracy. PLoS Neg/ Trop Dis 2012; 6(12): e1946. http://dx.doi. org/10.1371/journal.pntd.0001946. PMid:23272257.

Almeida MAO, Jesus EEV, Sousa-Atta MLB, Alves LC, Berne MEA, Atta AM. Clinical and serological aspects of Visceral Leishmaniasis in Northeast Brazilian dogs naturally infected with Leishmania chagasi. Vet Parasitol 2005; 127(3-4): 227-232. http://dx.doi. org/10.1016/j.vetpar.2004.10.010. PMid:15710523.

Alvar J, Canãvate C, Molina R, Moreno J, Nieto J. Canine Leishmaniasis. Adv Parasitol 2004; 57: 1-88. http://dx.doi.org/10.1016/ S0065-308X(04)57001-X. PMid:15504537.

Alvar J, Vélez ID, Bern C, Herrero M, Desjeux P, Cano J, et al. Leishmaniasis Worldwide and global estimates of its incidence. PLoS One 2012; 7(5): e35671. http://dx.doi.org/10.1371/journal.pone.0035671. PMid:22693548. 
Amusategui I, Sainz A, Rodríguez F, Tesouro MA. Distribution and relationships between clinical and biopathological parameters in canine leishmaniasis. Eur J Epidemiol 2003; 18(3): 147-156. http://dx.doi.org/10.1023/a:1023090929302. PMid:12733837.

Araujo AC, Costa AP, Silva IWG, Matos NNVG, Dantas ACS, Ferreira F, et al. Epidemiological aspects and risk factors for infection by Leishmania infantum chagasi in dogs from municipality of Petrolina, Northeastern Brazil. Vet Parasitol Reg Stud Rep 2016b; 3-4: 41-48. http://dx.doi.org/10.1016/j.vprsr.2016.07.001. PMid:31014498.

Araujo AC, Gonçalves NNVM, Dantas-Torres F, Ferreira F, Horta MC. Visceral Leishmaniasis in Petrolina, State of Pernambuco, Brazil, 2007-2013. Rev Inst Med Trop São Paulo 2016a; 58(0): 29. http://dx.doi.org/10.1590/s1678-9946201658029. PMid:27074323.

Arruda MM, Figueiredo FB, Marcelino AP, Barbosa JR, Werneck GL, Noronha EF, et al. Sensitivity and specificity of parallel or serial serological testing for detection of canine Leishmania Infection. Mem Inst Oswaldo Cruz 2016; 111(3): 168-173. http://dx.doi. org/10.1590/0074-02760150364. PMid:26910354.

Baneth G, Koutinas AF, Solano-Gallego L, Bourdeau P, Ferrer L. Canine leishmaniosis - new concepts and insights on an expanding zoonosis: part one. Trends Parasito/ 2008; 24(7): 324-330. http://dx.doi.org/10.1016/j.pt.2008.04.001. PMid:18514028.

Belo VS, Gregório EA, Teixeira-Neto RG, da Rocha Lima ACVM, Pereira AAS, Marcelino AP, et al. Reliability of techniques used in the diagnosis of canine visceral leishmaniasis by the national control program in Brazil: a survey in an area of recent transmission. Prev Vet Med 2017; 146: 10-15. http://dx.doi.org/10.1016/j.prevetmed.2017.07.011. PMid:28992913.

Belo VS, Werneck GL, Barbosa DS, Simões TC, Nascimento BWL, da Silva ES, et al. Factors associated with visceral Leishmaniasis in the Americas: a systematic review and meta-analysis. PLoS Neg/ Trop Dis 2013; 7(4): e2182. http://dx.doi.org/10.1371/journal. pntd.0002182. PMid:23638203.

Boarino A, Scalone A, Gradoni L, Ferroglio E, Vitale F, Zanatta R, et al. Development of recombinant chimeric antigen expressing immunodominant B epitopes of Leishmania infantum for serodiagnosis of visceral leishmaniasis. Clin Diagn Lab Immunol 2005; 12(5): 647-653. http://dx.doi.org/10.1128/CDLI.12.5.647-653.2005. PMid:15879027.

Borges LFNM, Lopes EGP, Freitas ACP, Silva MX, Haddad JPA, Silva JA, et al. Prevalence and spatial distribution of visceral leishmaniasis in dogs Juatuba, Minas Gerais, Brazil. Cienc Rural 2014; 44(2): 352-357. http://dx.doi.org/10.1590/S010384782014000200025

Brazil RP, Rodrigues AAF, Andrade JD Fo. Sand fly vectors of Leishmania in the Americas - a mini review. Entomol Ornithol Herpetol 2015; 4(2): 144. http://dx.doi.org/10.4172/2161-0983.1000144.

Camargo-Neves VLF, Katz G, Rodas LAC, Poletto DW, Lage LC, Spínola RMF, et al. Use of spatial analysis tools in the epidemiological surveillance of American visceral leishmaniasis, Araçatuba, São Paulo, Brazil, 1998-1999. Cad Saude Publica 2001; 17(5): 12631267. http://dx.doi.org/10.1590/S0102-311X2001000500026. PMid:11679900.

Carvalho MS, Souza-Santos R. Analysis of spatial data in public health: methods, problems, and perspectives. Cad Saude Publica 2005; 21(2): 361-378. http://dx.doi.org/10.1590/S0102-311X2005000200003. PMid:15905899.

Cesse EAP, Carvalho EF, Andrade PP, Ramalho WM, Luna L. Organização do espaço urbano e expansão do calazar. Rev Bras Saúde Mater Infant 2001; 1(2): 167-176. http://dx.doi.org/10.1590/S1519-38292001000200010.

Conti RV, Moura Lane VF, Montebello L, Pinto VL Jr. Visceral leishmaniasis epidemiologic evolution in timeframes, based on demographic changes and scientific achievements in Brazil. J Vector Borne Dis 2016; 53(2): 99-104. PMid:27353578.

Cordeiro LLLR, Silva EM, Santana-Lima VF, Porto WJN. Leishmaniose Visceral Canina na microrregião serrana dos Quilombos, leste alagoano, Alagoas, Brasil. Hygea-. Rev Bras Geog Med Saude 2016; 12(22): 169-176.

Cortes S, Vaz Y, Neves R, Maia C, Cardoso L, Campino L. Risk factors for canine leishmaniasis in an endemic Mediterranean region. Vet Parasitol 2012; 189(2-4): 189-196. http://dx.doi.org/10.1016/j.vetpar.2012.04.028. PMid:22575278.

Dantas-Torres F, Brito MEF, Brandão-Filho SP. Seroepidemiological survey on canine leishmaniasis among dogs from an urban area of Brazil. Vet Parasito/ 2006; 140(1-2): 54-60. http://dx.doi.org/10.1016/j.vetpar.2006.03.008. PMid:16621286.

Dantas-Torres F. Situação atual da epidemiologia da leishmaniose visceral em Pernambuco. Rev Saude Publica 2006; 40(3): 537541. http://dx.doi.org/10.1590/S0034-89102006000300024. PMid:16810380.

Dantas-Torres F. The role of dogs as reservoirs of Leishmania parasites, with emphasis on Leishmania (Leishmania) infantum and Leishmania (Viannia) braziliensis. Vet Parasitol 2007; 149(3-4): 139-146. http://dx.doi.org/10.1016/j.vetpar.2007.07.007. PMid:17703890.

Dohoo IR, Martin W, Stryhn H. Veterinary epidemiologic research. Charlottetown, Canadá: Atlantic Veterinary College; 2003.

Dujardin JC. Risk factors in the spread of leishmaniases: towards integrated monitoring? Trends Parasito/ 2006; 22(1): 4-6. http:// dx.doi.org/10.1016/j.pt.2005.11.004. PMid:16300999.

Fernandes ARF, Pimenta CLRM, Vidal IF, Oliveira GC, Sartori RS, Araújo RB, et al. Risk factors associated with seropositivity for Leishmania spp. and Trypanosoma cruzi in dogs in the state of Paraiba, Brazil. Rev Bras Parasitol Vet 2016; 25(1): 90-98. http:// dx.doi.org/10.1590/S1984-29612016010. PMid:26982555. 
Grimaldi GJr, Teva A, Ferreira AL, Dos Santos CB, Pinto IS, De Azevedo CT, et al. Evaluation of a novel chromatographic immunoassay based on Dual-Path Platform technology (DPP ${ }^{\circledR}$ CVL rapid test) for the serodiagnosis of canine visceral leishmaniasis. Trans $R$ Soc Trop Med Hyg 2012; 106(1): 54-59. http://dx.doi.org/10.1016/j.trstmh.2011.10.001. PMid:22137538.

Harhay MO, Olliaro PL, Costa DL, Costa CHN. Urban parasitology: visceral leishmaniasis in Brazil. Trends Parasitol 2011; 27(9): 403-409. http://dx.doi.org/10.1016/j.pt.2011.04.001. PMid:21596622.

Instituto Brasileiro de Geografia e Estatística - IBGE. Cities [online]. Rio de Janeiro: IBGE; 2011 [cited 2019 Sep 17]. Available from: http://www.ibge.gov.br/cidadesat/link.php?uf=ma

Julião FS, Souza BMPS, Freitas DS, Oliveira LS, Larangeira DF, Dias-Lima AG, et al. Investigação de áreas de risco como metodologia complementar ao controle da leishmaniose visceral canina. Pesq Vet Bras 2007; 27(8): 319-324. http://dx.doi.org/10.1590/S0100736X2007000800001.

Kulldorff M, Nagarwalla N. Spatial disease clusters: detection and inference. Statistic Med 1995; 14(8): 799-810. http://dx.doi. org/10.1002/sim.4780140809. PMid:7644860.

Laurenti MD, Rossi CN, Matta VLR, Tomokane TY, Corbett CEP, Secundino NFC, et al. Asymptomatic dogs are highly competent to transmit Leishmania (Leishmania) infantum chagasi to the natural vector. Vet Parasitol 2013; 196(3-4): 296-300. http://dx.doi. org/10.1016/j.vetpar.2013.03.017. PMid:23562649.

Laurenti MD, Santana Leandro MV Jr, Tomokane TY, De Lucca HRL, Aschar M, Souza CSF, et al. Comparative evaluationof the DPP ${ }^{\circledR}$ CVL rapid test for canine serodiagnosis in area of visceral leishmaniasis. Vet Parasito/ 2014; 205(3-4): 444-450. http://dx.doi. org/10.1016/j.vetpar.2014.09.002. PMid:25257505.

Leça NF Jr, Guedes PEB, Santana LN, Almeida VA, Carvalho FS, Albuquerque GR, et al. Epidemiology of canine leishmaniasis in southern Bahia, Brazil. Acta Trop 2015; 148: 115-119. http://dx.doi.org/10.1016/j.actatropica.2015.04.008. PMid:25917715.

Lira RA, Cavalcanti MP, Nakazawa M, Ferreira AGP, Silva ED, Abath FGC, et al. Canine visceral leishmaniosis: a comparative analysis of the EIE-leishmaniose-visceral-canina-Bio-Manguinhos and the IFI-leishmaniose-visceral-canina-Bio-Manguinhos kits. Vet Parasitol 2006; 137(1-2): 11-16. http://dx.doi.org/10.1016/j.vetpar.2005.12.020. PMid:16446034.

Maia CS, Pimentel DS, Santana MA, Oliveira GM, Pedrosa NA, Nascimento LA, et al. Análise espacial da leishmaniose visceral americana no município de Petrolina, Pernambuco. Hygea -. Rev Bras Geog Med Saude 2014; 10(18): $167-176$.

Marcili A, Sperança MA, da Costa AP, Madeira MF, Soares HS, Sanches CO, et al. Phylogenetic relationships of Leishmania species based on trypanosomatid barcode (SSU rDNA) and gGAPDH genes: Taxonomic revision of Leishmania (L.) infantum chagasi in South America. Infect Genet Evol 2014; 25: 44-51. http://dx.doi.org/10.1016/j.meegid.2014.04.001. PMid:24747606.

Marcondes M, Biondo AW, Gomes AA, Silva AR, Vieira RF, Camacho AA, et al. Validation of a Leishmania infantum ELISA rapid test for serological diagnosis of Leishmania chagasi in dogs. Vet Parasitol 2011; 175(1-2): 15-19. http://dx.doi.org/10.1016/j. vetpar.2010.09.036. PMid:21030153.

Mendonça IL, Batista JF, Schallig H, Cruz MSP, Alonso DP, Ribolla PEM, et al. The performance of serological tests for Leishmania infantum infection screening in dogs depends on the prevalence of the disease. Rev Inst Med Trop São Paulo 2017; 59(0): e39. http://dx.doi.org/10.1590/s1678-9946201759039. PMid:28591267.

Michel G, Pomares C, Ferrua B, Marty P. Importance of worldwide asymptomatic carriers of Leishmania infantum (L. chagasi) in human. Acta Trop 2011; 119(2-3): 69-75. http://dx.doi.org/10.1016/j.actatropica.2011.05.012. PMid:21679680.

Michelin AF, Maciel MOS, Okajima M, Nunes CM, Perri SHV, Bonfietti LX. Factors associated with positivity for canine visceral leishmaniosis in an endemic area in Brazil. Vet Parasito/ Reg Stud Rep 2018; 12: 13-16. http://dx.doi.org/10.1016/j.vprsr.2017.12.006. PMid:31014800.

Oliveira CDL, Assunção RM, Reis IA, Proietti FA. Spatial distribution of human and canine visceral leishmaniasis in Belo Horizonte, Minas Gerais State, Brazil, 1994-1997. Cad Saude Publica 2001; 17(5): 1231-1239. http://dx.doi.org/10.1590/S0102311X2001000500023. PMid:11679897.

Oliveira KM, Wainfas RL, Arnóbio A, Figueiró R. Ecological and social determinants of leishmaniasis in the Legal Amazon, Brazil. Acta Sci Technol 2013; 1(2): 13-19. http://dx.doi.org/10.17648/uezo-ast-v1i2.13.

Oliveira VVG, Alves LC, Silva VA Jr. Transmission routes of visceral leishmaniasis in mammals. Cienc Rural 2015; 45(9): $1622-1628$. http://dx.doi.org/10.1590/0103-8478cr20141368.

Otranto D, Dantas-Torres F. The prevention of canine leishmaniasis and its impact on public health. Trends Parasito/ 2013; 29(7): 339-345. http://dx.doi.org/10.1016/j.pt.2013.05.003. PMid:23746747.

Paltrinieri S, Solano-Gallego L, Fondati A, Lubas G, Gradoni L, Castagnaro M, et al. Guidelines for diagnosis and clinical classification of leishmaniasis in dogs. J Am Vet Med Assoc 2010; 236(11): 1184-1191. http://dx.doi.org/10.2460/javma.236.11.1184. PMid:20513195.

Pan American Health Organization - PAHO. Report Leishmaniases [online]. 2019 [cited 2019 Sep 10] Available from: http://iris. paho.org/xmlui/bitstream/handle/123456789/50505/2019-cde-leish-informe-epi-das-americas.pdf?ua=1 
Pfeiffer D, Robinson T, Stevenson M, Stevens K, Rogers D, Clements A. Spatial analysis in epidemiology. Oxford: Oxford University Press; 2008. http://dx.doi.org/10.1093/acprof:oso/9780198509882.001.0001.

Pimentel DS, Ramos RAN, Santana MA, Maia CS, Carvalho GA, Silva HP, et al. Prevalence of zoonotic visceral leishmaniasis in dogs in an endemic area of Brazil. Rev Soc Bras Med Trop 2015; 48(4): 491-493. http://dx.doi.org/10.1590/0037-8682-0224-2014. PMid:26132498.

Queiroz NMGP, Assis JD, Oliveira TMFS, Machado RZ, Nunes CM, Starke-Buzetti WA. Diagnóstico da Leishmaniose Visceral Canina pelas técnicas de imunoistoquímica e PCR em tecidos cutâneos em associação com a RIFI e ELISA-teste. Rev Bras Parasitol Vet 2010; 19(1): 434-440. http://dx.doi.org/10.1590/S1984-29612010000100007. PMid:20385057.

Rondon FCM, Bevilaqua CML, Franke CR, Barros RS, Oliveira FR, Alcântara AC, et al. Cross-sectional serological study of canine Leishmania infection in Fortaleza, Ceará state, Brazil. Vet Parasitol 2008; 155(1-2): 24-31. http://dx.doi.org/10.1016/j. vetpar.2008.04.014. PMid:18565676.

Santis B, Santos EGB, Souza CSFS, Chaves SAM. Performance of DPPTM immunochromathographic rapid test (IRT) for canine visceral leishmaniasis: comparison with other serological methods in suspected dogs from Cuiabá, Mato Grosso State, Brazil. Braz J Vet Res Anim Sci 2013; 50(3): 198-205.

Santos JML, Dantas-Torres F, Mattos MRF, Lino FRL, Andrade LSS, Souza RCA, et al. Prevalência de anticorpos anti-Leishmania spp em cães de Granhuns, Agreste de Pernambuco. Rev Soc Bras Med Trop 2010; 43(1): 41-45. http://dx.doi.org/10.1590/S003786822010000100010 . PMid:20305967.

Sevá AP, Mao L, Galvis-Ovallos F, Lima JMT, Valle D. Risk analysis and prediction of visceral leishmaniasis dispersion in São Paulo State, Brazil. PLoS Neg/ Trop Dis 2017; 11(2): e0005353. http://dx.doi.org/10.1371/journal.pntd.0005353. PMid:28166251.

Silva CB, Vilela JA, Pires MS, Santos HA, Falqueto A, Peixoto MP, et al. Seroepidemiological aspects of Leishmania spp. in dogs in the Itaguai micro-region, Rio de Janeiro, Brazil. Rev Bras Parasitol Vet 2013a; 22(1): 39-45. http://dx.doi.org/10.1590/S198429612013000100009 . PMid:24252952.

Silva DA, Madeira MF, Abrantes TR, Barbosa CJL Fo, Figueiredo FB. Assessment of serological tests for the diagnosis of canine visceral leishmaniasis. Vet J 2013b; 195(2): 252-253. http://dx.doi.org/10.1016/j.tvjl.2012.06.010. PMid:22789627.

Silva JD, Melo DHM, Costa JAG, Costa DF, Silva RBS, Melo MA, et al. Leishmaniose visceral em cães de assentamentos rurais. Pesq Vet Bras 2017; 37(11): 1292-1298. http://dx.doi.org/10.1590/s0100-736x2017001100016.

Silva RBS, Mendes RS, Santana VL, Souza HC, Ramos CPS, Souza AP, et al. Aspectos epidemiológicos da leishmaniose visceral canina na zona rural do semiárido paraibano e análise de técnicas de diagnóstico. Pesq Vet Bras 2016; 36(7): 625-629. http:// dx.doi.org/10.1590/S0100-736X2016000700011.

Silva-Abreu AL, Lima TB, Macedo AA, Moraes-Júnior FJ, Dias EL, Batista ZS, et al. Soroprevalência, aspectos clínicos e bioquímicos da infecção por Leishmania em cães naturalmente infectados e fauna de flebotomíneos em uma área endêmica na ilha de São Luís, Maranhão, Brasil. Rev Bras Parasitol Vet 2008; 17(Suppl 1): 197-203.

Sistema de Informação de Agravos de Notificação - SINAN. [online]. 2018 [cited 2018 Aug 10]. Available from: http://tabnet. datasus.gov.br/cgi/deftohtm.exe?sinannet/cnv/leishvPE.def

Sistema de Informação de Agravos de Notificação - SINAN. [online]. 2019 [cited 2019 Nov 2]. Available from: http://tabnet. datasus.gov.br/cgi/deftohtm.exe?sinannet/cnv/leishvPE.def.

Souza VAF, Cortez LRPB, Dias RA, Amaku M, Ferreira JS No, Kuroda RBS, et al. Space-time cluster analysis of American visceral leishmaniasis in Bauru, São Paulo State, Brazil. Cad Saude Publica 2012; 28(10): 1949-1964. http://dx.doi.org/10.1590/S0102311X2012001000013. PMid:23090174.

Teixeira-Neto RG, Silva ES, Nascimento RA, Belo VS, Oliveira CL, Pinheiro LC, et al. Canine visceral leishmaniasis in an urban setting of Southeastern Brazil: an ecological study involving spatial analysis. Parasit Vectors 2014; 20(7): 485. http://dx.doi.org/10.1186/ s13071-014-0485-7. PMid:25326767.

Travi BL, Cordeiro-da-Silva A, Dantas-Torres F, Miró G. Canine visceral leishmaniasis: diagnosis and management of the reservoir living among us. PLoS Neg/ Trop Dis 2018; 12(1): e0006082. http://dx.doi.org/10.1371/journal.pntd.0006082. PMid:29324838.

Werneck GL, Costa CH, Walker AM, David JR, Wand M, Maguire JH. Multilevel modelling of the incidence of visceral leishmaniasis in Teresina, Brazil. Epidemiol Infect 2007; 135(2): 195-201. http://dx.doi.org/10.1017/S0950268806006881. PMid:16824254.

Werneck GL. Forum: geographic spread and urbanization of visceral leishmaniasis in Brazil. Introduction. Cad Saude Publica 2008; 24(12): 2937-2940. http://dx.doi.org/10.1590/S0102-311X2008001200023. PMid:19082285.

World Health Organization - WHO. Leishmaniasis, Epidemiological situation [online]. Geneva: WHO; 2015 [cited 2018 Sept 16]. Available from: http://www.who.int/leishmaniasis/burden/en/

World Health Organization - WHO. Leishmaniasis, Epidemiological situation [online]. Geneva: WHO; 2017 [cited 2018 Aug 18]. Available from: http://www.who.int/leishmaniasis/burden/en/ 